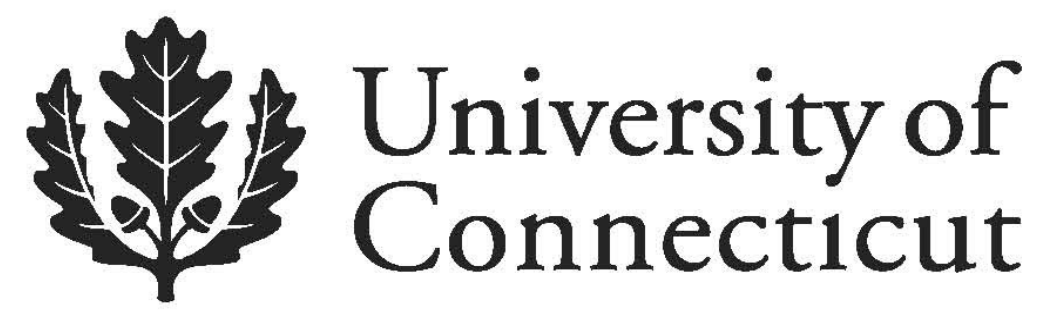

Department of Economics Working Paper Series

Inequality of Wealth in the Ottoman Empire: War, Weather, and Long-term Trends in Eighteenth Century Kastamonu

Metin M. Coşgel

University of Connecticut

Boğaç A. Ergene

University of Vermont

Working Paper 2011-29

December 2011

341 Mansfield Road, Unit 1063

Storrs, CT 06269-1063

Phone: (860) 486-3022

Fax: (860) 486-4463

http://www.econ.uconn.edu/

This working paper is indexed on RePEc, http://repec.org/ 
Inequality of Wealth in the Ottoman Empire:

War, Weather, and Long-term Trends in Eighteenth Century Kastamonu

METIN M. COŞGEL AND BOĞAÇ A. ERGENE

\begin{abstract}
This article offers a quantitative analysis of wealth inequality in the Ottoman Empire, employing data from probate inventories (terekes) of eighteenth-century Kastamonu, a town located in northern Anatolia. Extracting information on the wealth levels and personal characteristics of individuals, we estimate aggregate measures of wealth inequality, namely the Gini Coefficient, the coefficient of variation, and the wealth shares of the wealthiest 10 and 25 percents of population. We use regression analysis to identify the time trend of wealth inequality and determine how warfare, significant weather events, macroeconomic variables, and shifts in population characteristics affected it.

Journal of Economic Literature Classification: D3, D6, E3, E6, I3, J1, N3, N9, O53, Keywords: wealth, inequality, war, weather, Ottoman Empire
\end{abstract}

Metin Coşgel is Professor of Economics at the University of Connecticut, Unit 1063, 341 Mansfield Road, Storrs, CT 06269-1063. Boğaç Ergene is Associate Professor of History at the University of Vermont, 133 South Prospect Street, Burlington, VT 05405. E-mails: metin.cosgel@uconn.edu and bogac.ergene@uvm.edu. The authors are grateful to the editor and anonymous referees of the Journal of Economic History for very useful comments and suggestions for improvement. 


\section{Inequality of Wealth in the Ottoman Empire: \\ War, Weather, and Long-term Trends in Eighteenth Century Kastamonu}

Despite the significant body of literature that has accumulated on the distribution of wealth in modern economies and on the relationship between inequality and industrialization, research on preindustrialized economies has been slow to progress. ${ }^{1}$ This is primarily due to the lack of individual level data on wealth before the nineteenth century. The literature is particularly weak for non-western societies, where the lack of longitudinal data has prevented researchers from studying the long term evolution of inequality.

This paper offers a quantitative analysis of wealth inequality in the Ottoman Empire, focusing on the town of Kastamonu, located in northern Anatolia, in the course of the eighteenth century. Recent literature on the economic history of the Ottoman Empire has argued that the eighteenth century was a period of major economic, political, and institutional transformations. ${ }^{2}$ Although economic historians of the Empire have drawn a variety of inferences about these institutional changes and wealth distribution, they have not examined these inferences systematically. In a first attempt towards filling this gap, we construct wealth from the court records of Kastamonu and use the data to analyze patterns and sources of inequality in the eighteenth century.

\footnotetext{
${ }^{1}$ For reviews of research on inequality, see Atkinson and Bourguignon, Handbook of Income Distribution, Persson and Tabellini,"Is Inequality Harmful, and van Zanden, "Inequality."

${ }^{2}$ See, for example Faroqhi, "Declines and Revivals," Genç, “A Study,” Pamuk, "The Evolution of Financial Institutions,"and Salzmann, “An Ancien Régime Revisited.”
} 
The paper is organized around two objectives. The first is to determine the evolution of wealth inequality in Kastamonu during the eighteenth century. Our primary sources of data are the probate estate inventories (terekes) as found in the court records (sicils) of this town. We estimate aggregate measures of wealth inequality, namely the Gini Coefficient, the coefficient of variation, and the wealth shares of the top 10 and top 25 percents of the population. We do so for each year for which the data are complete to identify simple patterns in the evolution of inequality over time. The second objective is to identify the factors that affected the distribution of wealth. We use regression analysis to identify the time trend of wealth inequality and to determine the impact of warfare, significant weather events, macroeconomic variables, and shifts in population characteristics.

Our results are also related to the literature on the causes of the relative backwardness of the Islamic Middle East. A longstanding presumption in this literature has been that wealth was more equally distributed in the region than in faster growing areas of the world, a difference with potential implications for development. ${ }^{3}$ Viewing fragmentation of wealth as a barrier to capital accumulation, some researchers have identified low and stagnant inequality before the nineteenth century to be a significant obstacle to long-term development in Islamic societies. ${ }^{4} \mathrm{By}$

\footnotetext{
${ }^{3}$ See, for example, İnalc1k and Quataert, An Economic and Social History, pp. 44-54.

${ }^{4}$ For example, Kuran, The Long Divergence, has recently attributed wealth fragmentation and consequent underdevelopment to Islamic law of inheritance and other institutional bottlenecks. Coşgel and Ergene, “Intergenerational Wealth Accumulation and Dispersion," p 274, however, show that "inheritance system was not a major factor in wealth accumulation and inequality". See also Persson and Tabellini, "Is Inequality Harmful," and Alesina and Rodrik, "Distributive Politics," for counter-arguments about the general relationship between inequality and growth.
} 
determining the evolution of wealth inequality in one context, our study launches a critical examination of presumptions about premodern inequality.

\section{WEALTH INEQUALITY IN EIGHTEENTH CENTURY KASTAMONU}

The study of wealth inequality in western economies has a long history. From Alice Hanson Jones to Lee Soltow and Jan Luiten van Zanden, scholars have debated the level and trends in inequality in pre-industrial societies. As van Zanden notes, however, "[c]omparable research on nonindustrialized countries has been slow to develop." 5

For a quantitative analysis of wealth inequality in the Ottoman Empire, we use data from the court records of Kastamonu, the administrative center of the sub-province (sancak) by the same name. We have chosen this town because of its size, representativeness, and fairly complete court records for much of the eighteenth century. Tax records from this period indicate that the population of the town and the adjacent seventy-five or so villages was around 3,500 to 4,000 households. Since there is no indication of major demographic fluctuations during the eighteenth century, these figures are consistent with John Kinneir's suggestion that town's population was around 12,000 in $1814 .{ }^{6}$ Demographic information thus indicates that Kastamonu

${ }^{5}$ van Zanden, “Inequality,” p. 58. Since Kuznets’ pioneering study of income and wealth inequality titled "Economic Growth and Income Inequality," numerous researchers have analyzed the relationship between inequality and growth in different societies and periods of history. See Deininger and Squire, "New Ways," for reviews of Kuznets hypothesis. Piketty, Postel-Vinay, and Rosenthal, "Wealth Concentration in a Developing Economy," offers a full evaluation based on evidence from wealth in Paris and in France over the last two centuries. For inequality in premodern Europe, see Soltow and van Zanden, Income and Wealth Inequality, and Hoffman, Jacks, Levin, and Lindert, "Real Inequality.".

${ }^{6}$ Kinneir, Journey. Based on an urban history of the town, Eyüpgiller, Bir Kent Tarihi, does not regard the eighteenth century as a major era of construction. 
was a medium-sized town in contemporary standards. The vast majority of the inhabitants of the region were Muslim and Turkish-speaking although we are aware of the existence of a Christian minority. $^{7}$

Economic activities in the town and its surroundings, not unlike most locations in central and eastern Anatolia, consisted of primarily agriculture and animal husbandry. Similar to households in other Ottoman lands, inhabitants worked in small peasant farms producing cereal grains, rice, fruits, and vegetables. ${ }^{8}$ Linen-, silk-, cotton-, and woolen-cloth production as well as cloth-dying and tanning are known to have existed between the sixteenth and the eighteenth centuries. Timber production, copper mining, and copperware industry were also important activities. $^{9}$

The lack of extraordinary characteristics or special strengths makes Kastamonu ideally suited for analysis of inequality in a typical medium-sized Ottoman town. It was located on at least two trade routes that linked eastern and southern Anatolia to Istanbul with commercial ties to important central-Anatolian towns of Ankara and Kayseri. ${ }^{10}$ We have no indication, however, that major inter-regional and international trade activity existed in or around the town that might, for example, resemble the mohair industry in Ankara, which was located about 250 kilometers south. According to Colin Heywood, the town was a relatively obscure and isolated location

\footnotetext{
${ }^{7}$ Heywood, "Kastamonu,” p. 438.

${ }^{8}$ Ergene, A Local Court, ch. 2. Pamuk, "Institutional Change,” pp. 229-230, suggests that agriculture sustained the economic livelihood of as much as the 90 percent of the Ottoman population and also carried the major burden of the Ottoman finances.

${ }^{9}$ Ergene, A Local Court, ch. 2; Eyüpgiller, Bir Kent Tarihi, pp. 44-6.

${ }^{10}$ Faroqhi, Towns and Townsmen, pp. 225-7; Karagöz, “XVII. ve XVIII. Asırlarda,” p. 266.
} 
during Ottoman times. ${ }^{11}$ Just like hundreds of remote, smaller towns in the interior, it remained cut-off from major commercial developments that historians identified in Western Anatolia, the Levant, and specific Balkan locations in the eighteenth century. ${ }^{12}$

The probate estate inventories (tereke) of Kastamonu's inhabitants are quite complete for the eighteenth century, making it well-suited for quantitative analysis of wealth. To construct data on wealth, we extracted information from about 1,600 estate inventories of Muslim male adults as found in 60 court registers of Kastamonu, ${ }^{13}$ covering, with lapses, the ninety-year period from 1713 to $1802 .{ }^{14}$ Prepared by court officials at the request of the heirs, an estate inventory provides detailed information about the wealth and legal heirs of an individual at his or her death. Typically, these documents begin with identifying the deceased by providing their full names, including their honorific titles if they were male, the names and titles of their fathers, and the names of the villages or quarters in which they lived. They then list the names, titles, and whereabouts of all surviving heirs and also specify how they were related to the deceased. ${ }^{15}$ This

\footnotetext{
${ }^{11}$ Heywood, Kastamony, p. 738.

${ }^{12}$ Salzmann, "Measures of Empire”; Barkey, Empire of Difference, ch. 7; Kasaba, The Ottoman Empire.

${ }^{13}$ We excluded from the sample incomplete inventories and the inventories of those who were not natives of Kastamonu but died while they were visiting the town.

${ }^{14}$ We consulted the microfilm copies of Kastamonu court registers, which are stored in the National Library of Turkey, in Ankara. This collection begins in 1095/1684. The earliest court registers contain estate inventories only sporadically. Thus, we chose to start coverage at a later date, when the quantity of documentation improves. Our dataset contains estates for forty-nine years of the ninety-year span we study in this article.

${ }^{15}$ The Islamic law of inheritance contains a complicated set of requirements about who should be included among legal heirs and what proportions of the estates they are entitled to acquire. For a detailed discussion of these rules and their economic implications, see Ergene and Berker, "Wealth and Inequality."
} 
information is followed by the amounts of cash and itemized lists and appraised values of the property (for example, houses, gardens, animals, orchards, and personal property) included in the estates. ${ }^{16}$ For individuals with outstanding obligations, the inventories state the identities of creditors and owed amounts, information that allows us to calculate the net value of an individual's estate by deducting the debts and outstanding obligations from the total value of his or her assets. Finally, the inventories specify the exact values of the shares allotted to individual heirs according to Islamic inheritance practices.

Despite their value as historical sources, estate inventories have limitations. ${ }^{17}$ Although all Muslim estates were supposed to be divided according to Islamic rules of inheritance, the court's involvement in estate divisions, which necessitated the composition of probate records, was not a legal requirement. The court personnel appraised and divided the estates when there was a potential conflict among the heirs. Also, the terekes tend to under-represent the poor, women, non-Muslims, and rural population, and they over-represent the elderly. Some individuals could be absent from records in an attempt to avoid the court's involvement in the appraisal and division of estates since courts charged a fraction of the estate's overall value as

\footnotetext{
${ }^{16}$ Tax farms and state-owned land (miri) to which individuals had usufruct rights are not included in terekes. Income and salaries generated by charitable endowments (evkaf) in which individuals frequently held hereditary positions are also not reported in these documents.

${ }^{17}$ In this regard Ottoman terekes are comparable to Western probate inventories. See Arrondel and Grange, “Transmission and Inequality of Wealth"; Main, "Probate Records"; and Jones, Wealth of a Nation to Be, for limitations of probate inventories as historical sources.
} 
“inheritance tax" (resm-i klsmet), in addition to a number of lump-sum fees for its service. ${ }^{18}$ Nevertheless, the Islamic law or its Ottoman practice did not exclude any Muslim estates from being divided by court officials due to the age, mental state, or legal status of the deceased or their surviving heirs. ${ }^{19}$

Although we do not have direct information on precisely what percentage of the deaths in Kastamonu ended up in estate inventories, it is possible to offer a rough estimate. For a low estimate of this ratio, take the annual crude death rate to be as high as 0.035 percent in eighteenth-century Kastamonu ${ }^{20}$ and that the average household contained five individuals. These figures would give an estimate of the total number of deaths in the town of Kastamonu and seventy-two adjacent villages - which were under the jurisdiction of the "judgeship" (kaza) of Kastamonu - to be between 55,000 $(0.035 * 3,500$ households $* 5$ persons per household $* 90$ years) and 63,000 $(0.035 * 4,000$ households $* 5$ persons per household $* 90$ years $)$ during the entire period. Assuming that half of these deaths belonged to females and about 15 percent of them to non-Muslims ${ }^{21}$ (whose estates were not subject to the Islamic rules of inheritance), we

\footnotetext{
${ }^{18}$ Ergene, "Costs of Court Usage," p. 29 observed that the court charged on average about 3.4 percent of the gross value of the estates of in mid-eighteenth-century Kastamonu. However, this rate also varied substantially among different estates and could be as high as 7 percent.

${ }^{19}$ The estates of the deceased without heirs were appropriated by local military-administrative authorities such as the governor or sub-governor. The inventories of these estates were prepared by court officials and recorded in court registers.

${ }^{20}$ Wrigley and Schofield, The Population History of England, pp. 181-2, report crude death rate for preindustrial France and Italy as 35 per 1,000, although this figure is likely to be significantly lower ( 25 to 30 per 1,000) for preindustrial England and Wales. No comparable figure exists for preindustrial Middle East.

${ }^{21}$ The accounts of nineteenth-century European travelers suggest that the non-Muslim inhabitants of Kastamonu
} 
estimate that between about 23,000 and 27,000 Muslim males died between 1713 and 1802. This result indicates that our sample of 1,600 inventories represents about 6 to 7 percent of all Muslim male deaths during this period. For an alternative approach to estimating this ratio, we can use Kinneir's figure $(12,000)$ for town population which he suggested for 1814. Suppose the average population of the town was 12,000 during our period and that 90 percent of inventories $(0.90 \mathrm{x}$ $1,600=1,440$ ) belonged to urban residents. ${ }^{22}$ Using the same crude death ratio as above and assuming (as we did above) that half of these deaths belonged to females and about 15 percent of them to non-Muslims, we would estimate the total number Muslim male deaths in the town alone to be $16,605(0.035 * 12,000$ inhabitants * 90 years * 0.85 Muslims * 0.5 males $)$. This would indicate a slightly higher estimate of about 9 percent $(1,440 / 16,605)$ of deaths being recorded in inventories.

Since estate inventories cover a sample of population, we need to make explicit the assumptions that must hold for the wealth information recorded in inventories to be truly representative of the overall population. By focusing on the Muslim male population recorded in inventories, we assume that the distribution of wealth did not differ systematically between men and women and between Muslims and non-Muslims and that the proportion of estates inventoried remained constant over time. The latter assumption may seem difficult to justify since the number of inventories increased significantly over time (see Table 1). This would present a problem if the rise was caused by a change in the rule on which estates were

constituted as much as fifteen percent of the population. Heywood, “Kastamonu,” p. 738.

${ }^{22}$ In our sources, about 90 percent of the deceased are identified as residents of the town of Kastamonu although many of these people also owned property (houses, orchards, etc.) in the surrounding villages. 
inventoried, for example if a wealth limit that was initially required to be inventoried was lifted at some point or lowered gradually over time. This would clearly change the segments of the population included in estate inventories and accordingly raise the inequality of wealth observed in our sample. There is no indication, however, that the rules or practices of estate divisions changed over time, making it difficult to explain why the numbers of estate inventories per year increased during the eighteenth-century. Given the lack of any major demographic change over time, we can only suggest that this increase must be related to the possible changes in the nature of the relationship between the court and the local community. Similar increases in the numbers of other types of documents (contracts, litigation summaries, etc.) in the same period support our impression that the court and its legal/notarial services became gradually more popular or accessible for reasons that are not clear to us. Therefore, we do not believe that the rise in sampling ratio introduces a significant bias to our calculations. In addition, to ensure that our results on the evolution of wealth consider the sample variation appropriately, we control for the number of inventories and the personal characteristics of recorded individuals through regression analysis.

\section{***Table 1 and Figure 1 should be about here ***}

To determine the evolution of wealth inequality in Kastamonu in the eighteenth century, we use the wealth data estimated from probate inventories and calculate for each year the Gini Coefficient, the coefficient of variation, and the wealth shares of the top 10 percent and the top 25 percent of the population as different measures of wealth inequality. ${ }^{23}$ We excluded from this

\footnotetext{
${ }^{23}$ To ensure that the trend observed in Figure 1 is robust to the choice of inequality measure, we calculated various other measures, including relative mean deviation, standard deviation of logs, and Theil entropy. The results of our
} 
analysis five years for which the number of inventories available in court records was too low to calculate measures of inequality. To give a preliminary impression of how wealth inequality changed over time, we list on Table 1 the summary statistics of these measures in twenty-year intervals. For a graphical illustration of the trend, Figure 1 shows how the 10-year moving averages of these measures changed between 1713 and 1802 . The trend was clearly a sharp rise in Wealth inequality in Kastamonu until about the last quarter of the eighteenth century, a finding that is consistent with those found by studies of long term inequality in Europe before the industrial revolution. ${ }^{24}$ Table 1 also includes the average levels of wealth and prices in each period, two macroeconomic indicators that rose significantly over time. ${ }^{25}$

\section{SOCIAL POSITIONS AND WEALTH INEQUALITY}

The next task is to understand the determinants of inequality and why it rose during much of the eighteenth century. To explain steady changes in the distribution of wealth and income, economic historians have identified various spontaneous processes affecting social stratification, such as the migration of population among sectors and changes in the functional distribution of income or earnings potentials, as basic determinants of inequality. ${ }^{26}$ Some of these factors could similarly be responsible for changes in the distribution of wealth in Kastamonu. If we can

analysis are consistent among these measures.

${ }^{24}$ Soltow and van Zanden,Income and Wealth Inequality; Hoffman, Jacks, Levin, and Lindert, "Real Inequality."

${ }^{25}$ The price information comes from the consumer price index for Istanbul constructed by Özmucur and Pamuk, "Real Wages." This index is consistent with the prices of select food and consumer products from the lists of official prices (narh) as found in Kastamonu court registers. Albanesi, "Inflation and Inequality," has found inflation to be positively linked to inequality.

${ }^{26}$ van Zanden, "Inequality." 
identify systematic shifts in social stratification during our period, we can analyze their effect on inequality.

Court records about individuals include honorary titles, which give information on social positions. Honorary titles appear in court records as parts of men's names, and in the absence of surnames and other indicators of socioeconomic status they help to distinguish individuals according to their affiliation with the provincial administrative structure and relative positions within the community. They signify individuals who possessed specific types of professional training or education, who performed various sorts of military/administrative or judicial/religious functions, and who enjoyed the socioeconomic privileges associated therewith. In addition to exemption from taxation, these benefits included economic compensation for specific services as well as varying degrees of communal influence associated with their involvement in the provincial administration.

Based on honorary titles we can determine if a man belonged to the military/administrative establishment (seyfiyye, in Ottoman Turkish) or the judicial/religious one (ilmiyye). If a man had no title attached to his name, he belonged to neither group. Seyfiyye included those men with military/administrative responsibilities or affiliations, such as governors, members of the police force, and the officers as well as the rank-and-file of the provincial militia. ${ }^{27}$ Ilmiyye, on the other hand, was composed of individuals with religious and

\footnotetext{
${ }^{27}$ In this study we identify the following honorary titles as the primary indicators of military/administrative status: $A \breve{g} a, B e s ̧ e$, and Be $\breve{g}$. Other military designations indicating specific military/administrative responsibilities always accompanied these three titles, which is why we designate the latter as the primary markers of military/administrative status.
} 
judiciary responsibilities or affiliations, such as local magistrates (qadis), jurisconsults (muftis), and mosque imams. ${ }^{28}$

In addition to differentiating between title-holders who belonged to military/administrative and judicial/religious establishments, we can further identify those who belonged to the elite group within each category. According to recent research on Ottoman titles, Ağas were the wealthiest, most prestigious, and highest ranking members of the military/administrative establishment and Efendis had the same status in the judicial/religious establishment. ${ }^{29}$ These groups included individuals who collectively managed the official affairs of the town and its environs in different capacities, played communal leadership roles, and also took advantage of the economic opportunities available in their locations. ${ }^{30}$ We therefore identified $A \breve{g} a$ s as 'elite military/administrative title-holders,' and Efendis as 'elite religious/judicial title-holders.' The rest of the estate-owners in our sample, "non-elite titleholders" and "men-without-titles," did not share their economic and social privileges.

To see how social positions changed in Kastamonu during the eighteenth century, we list on Table 2 the average proportions of different groups of title-holders in twenty-year intervals. After an initial rise until about 1730s and fall in the next twenty years, the proportion of judicial/religious and military/administrative elites remained about the same in the second half of the eighteenth century. The proportion of individuals with non-elite titles, on the other hand, fell significantly during this period, while the proportion of individuals with no title rose. We will

\footnotetext{
${ }^{28}$ Such individuals carried the following titles: Efendi, Molla, Halife, Çelebi, and Dede. Other designations that indicate affiliation with the religious establishment accompanied these titles.

${ }^{29}$ Ergene and Berker, "Wealth and Inequality."

${ }^{30}$ Barkey, Empire of Difference, ch. 7.
} 
explore in more detail below whether these patterns in population shifts help to explain the longterm trend of wealth inequality in Kastamonu in the eighteenth century.

\section{ADVERSE SHOCKS AND WEALTH INEQUALITY}

Beyond long term shifts in population, shorter-term but high-impact shocks may also contribute to wealth inequality. We would expect two specific types of shocks to affect wealth inequality in the Ottoman Empire during the eighteenth century, namely manmade disasters such as warfare and natural phenomena such as extreme weather events. Obviously, war and weather patterns are not the only variables that could generate shocks in an economy. However, since we lack quantitative data on other such variables (including, for example, frequency and intensity of plague or natural disasters such as wild-fires or earthquakes in the region), our analysis remains limited to these two.

Warfare could affect the inequality of wealth by disrupting the allocation and distribution of resources. Its net effect can vary from one war to the next depending on how it is financed and how its impact spreads among individuals and sectors of the economy. It might increase inequality if it creates opportunities for the wealthy, such as through greater demand for their capital or products, which are not available to other members of the society. Conversely, war might reduce inequality if the government finances it by taxing the wealth disproportionately heavily or if it disrupts economic activities, such as trade and manufacturing, through which they accumulate wealth. The net effect may also depend on the primary source of wealth, because whereas war may boost economic activity in some sectors, such as mining and metallurgy, it can 
disrupt it in others, such as farming and maritime trade. ${ }^{31}$ Yet another factor affecting the inequality of wealth may be the changes in relative prices of factors of production and in the values of assets, particularly real estate, capital equipment, and durable goods.

The relationship between war and economy has yet to be empirically investigated in Ottoman historiography. Some historians have proposed a negative association between extended periods of war and the overall performance of the economy in the seventeenth and eighteenth centuries. ${ }^{32}$ In a hypothetical assessment of war's impact on industrial production in the eighteenth century, Mehmet Genç has suggested that war-time needs and government policies to satisfy them in this period must have led to industrial decline and economic contraction. More recently, Rhoads Murphey has argued that the nature of the relationship between war and economic performance could be different from what Genç suggested. ${ }^{33}$ Questioning Genç's observations and suppositions on the scale and consistency of the government's attempts to purchase war supplies at low, fixed prices and the responsiveness of pre-modern Ottoman economy to war-time demands, he has observed a positive relationship between war and trade and argued that war-time allowances and cash-bonuses that troops received must have not only stimulated the local economies where soldiers were stationed during the times of conflict but also trickled down to and impacted their own regions after they returned home. Neither Genç nor Murphey or others, however, have examined the war's effect on wealth inequality quantitatively.

\footnotetext{
${ }^{31}$ Silberling, The Dynamics of Business, pp. 58-63; Soltow and van Zanden, Income and Wealth Inequality, pp. 8691.

32 Tabakoğlu, Gerileme Dönemine Girerken; Özkaya, XVIII. Yüzyılda.

${ }^{33}$ Genç, "Osmanlı Ekonomisi ve Savaş"; Murphey, Ottoman Warfare.
} 
Previous arguments about the effect of war on the economy suggest various ways through which it could alter the distribution of wealth in Kastamonu in the eighteenth century. On the one hand, one would expect war to stimulate economic activities in certain sectors and possibly raise inequality if the owners of war-related businesses benefitted more than other inhabitants of town from the higher demand. Although the region was too far from all major war theaters during this period, several of town's industries could still be affected by military conflicts. As noted, copper mining was a major economic activity, in particular in the neighboring district of Küre. ${ }^{34}$ During times of military conflict the central government increased its demand for copper and claimed all production in the region. ${ }^{35}$ Other economic activities could also be important for military purposes. Timber, linen textiles, and ropes produced in the sub-district were critical especially for the navy but were also used for other military purposes. Court records similarly indicate that during times of war or war preparation the demand by the central government for food supplies (especially cereals) increased. On the other hand, the net effect on these sectors could still be negative if the government imposed higher taxes on them to finance the war or if it paid for their government-purchased goods and services at artificially low, below-market prices.

To consider the net effect of war, we can compare the means and standard deviations of different measures of inequality in years of war with years of peace, as can be seen in Table 3.

\footnotetext{
${ }^{34}$ In the late seventeenth and eighteenth centuries, the rights to extract copper were auctioned regularly and copper extraction was considered as one of the major tax-farms in the region. In the sixteenth century most of the copper extracted in the area was either sent to Istanbul, or was transported to the south towards Syria via the route of Amasya, Tokat and Sivas. Archival sources also indicate that a large proportion of copper produced in the region were used in the Ottoman Arsenal (Tophane-i Amire) in Istanbul for the production of cannons and other types of weaponry. For details, see Yaman, “Küre Bakır Madenine Dair Vesikalar”; Faroqhi, Towns and Townsmen, p. 175. ${ }^{35}$ Yaman, "Küre Bakır Madenine Dair Vesikalar”.
} 
We used chronologies provided by Virginia Aksan, Halil İnalcık, and Donald Quataert to identify the years that the Ottoman Empire engaged militarily other major Euro-Asian powers. ${ }^{36}$ Although such a comparison does not take into consideration the intensity of warfare, it will nevertheless help us to examine the effect of war on wealth inequality. As Table 3 shows, all measures of inequality were higher for peacetime than war years, suggesting that war reduced the inequality of wealth.

***Table 3 should be about here***

Natural phenomena such as extreme weather events can also affect wealth inequality if they impact economic sectors and population groups differently. As external shocks to the generation and distribution of wealth, they can affect not just the level of wealth through destruction but its inequality among individuals through differential impact. Significant fluctuations in weather patterns, for example, can affect rural and urban economic activities differently, causing transfers of income and wealth among individuals employed in these sectors. Similarly, rich and poor segments of population could differ in their abilities to access loans after a disaster or to diversify assets as self-insurance against them. Studies of distributional impacts of climate change and natural disasters in modern times have shown that "[n]atural disasters tend to exacerbate existing differences across a population." ${ }^{37}$

Although there have been recent studies of the effect of climate on political and economic crisis in the Ottoman Empire, no systematic analysis exists on how extreme weather events have impacted wealth inequality. To examine the effect of weather on inequality in the Ottoman

\footnotetext{
${ }^{36}$ Aksan, Ottoman Wars; İnalcık and Quataert, An Economic and Social History. The major periods of war are the years 1714-18, 1723-27, 1730-39, 1743-46, 1768-74, 1878-92, and 1799-1802.

${ }^{37}$ Ibarrarán and Ruth, "Climate Change and Natural Disasters," p. 46.
} 
Empire, we use data from a dendroclimatology study conducted for the Kastamonu region. ${ }^{38}$ In this study the authors reconstruct a detailed record of the yearly precipitation levels from the rings of a sample of living and dead oak-trees in the Pınarbaşı area, located about eighty kilometers north-west of modern city of Kastamonu. They also compare their findings based on tree rings to the available historical information on weather patterns from the secondary literature and archival materials and identify the wet and the dry years for a period that spans from 1635 to 2000. Since the effects of draught and excessive rain can be different, we distinguish between "dry" (corresponding to precipitation that is below 1-standard deviation of the mean) and "wet" (precipitation that is above 1-standard deviation of the mean) years.

To take a preliminary look at how weather conditions affected wealth inequality, we compare the means and standard deviations of different measures of inequality under different weather circumstances, namely between years of dry, wet, and normal (precipitation within 1standard deviation of the mean) weather conditions, as seen in Table 3. Whereas the averages of all three measures were generally higher in dry years, there was no consistent difference between wet and normal years.

\section{THE DETERMINANTS OF WEALTH INEQUALITY}

Since positional shifts, macroeconomic trends, and adverse shocks affected inequality simultaneously, we need to examine these influences jointly through regression analysis. To ensure the robustness of results to differences between measures of inequality, we ran the same model separately by taking the Gini Coefficient, the coefficient of variation, and the wealth

\footnotetext{
38 The data come from Akkemik, Dağdeviren, and Aras, “A Preliminary Reconstruction.” For a study of the effect of climate on political and economic crisis in the Empire, see White, "Ecology, Climate, and Crisis."
} 
shares of the top 10 percent and the top 25 percent of the population as dependent variables. Since each of these measures has restricted values, we used a Tobit model to estimate influences on wealth inequality.

The explanatory variables consist of three groups of factors. The first group includes social positions that reflect in the proportions of honorary titles and macroeconomic indicators. More specifically, to consider the effect of positional shifts in society, we included the proportions of judicial/religious elites, military/administrative elites, and individuals who held no titles as explanatory variables, omitting the category of those with non-elite titles for comparison. Including variables on the social positions of individuals allows us to control for changes in sample characteristics over time. The macroeconomic variable of primary interest is the (natural $\log$ of) average real wealth. The logarithmic specification allows us to separate this influence into two channels, namely the (natural logs of) average nominal wealth and consumer price index.

The second group consists of variables that depict the effects of adverse shocks. To consider the effect of war, we constructed a dummy variable that distinguishes war years (1) from the years of peace (0). We similarly constructed two dummy variables for different weather conditions. The first is "dry," taking the value of 0 if precipitation is normal (within 1-standard deviation of the mean) and 1 if it is too low (below 1-standard deviation of the mean). The variable "wet," similarly takes the values of 0 if precipitation is normal (within 1 -standard deviation of the mean) and 1 if it is excessive (above 1-standard deviation of the mean).

Determining the net effects of war and extreme weather conditions is further complicated by the fact that the immediate and longer term effects of these events may be different. Whereas the heavy taxation or confiscation of property during wartime would reduce wealth immediately, 
it may take longer to realize the positive effects of war on the accumulation of wealth due to higher demand. Similarly, the immediate and long term effects of extreme weather conditions may be different depending on local market conditions and price elasticity of demand. To consider the delayed effects of these factors separately, we included not just the current year's war and weather conditions but also the one year lagged values of these variables.

In the final group we included three other variables that would be expected to affect the observed wealth inequality, namely a dummy variable for the period after 1767 , the number of probate inventories found in the court records, and a "time" variable. The first variable controls for the effects of deteriorating fiscal conditions and the economic policies adopted during the extended, difficult period of war after 1767. Whereas the Ottomans experienced a period of relative peace and fiscal stability during the decades leading to the Ottoman-Russian wars of 1768-1774, the fiscal circumstances first deteriorated during these wars and then became worse when the Ottomans entered in war with Russia and Austria in 1787. The government's attempts of revenue extraction in these occasions created a serious burden on the entire population, including holders of lifetime tax-farms (malikane), high-level state functionaries, and the wealthy in general. In addition to war-time taxes imposed on the entire population, starting with the war of 1768-72, malikane-holders were required pay a war-time tax called cebelü bedeliyesi, equivalent to 15 percent of the initial lump-sum that they had paid for their malikanes. Additional war-time contributions were regularly expected of the wealthy after 1768, and confiscating (müsadere) private properties of affluent government officials became prevalent in the 1780 s. ${ }^{39}$ While we would expect these developments to worsen the economic circumstances

\footnotetext{
${ }^{39}$ For further details, see Cezar, Osmanlı Maliyesinde, p. 74, 110, and 135; Tabakoğlu, Gerileme Dönemine Girerken, pp. 295-300.
} 
of the wealthiest segments of the society, it does not necessarily follow that they carried a proportionally heavier financial burden during the times of financial stress and war. To determine if there was a qualitative shift in wealth inequality during the period of extended wars and new economic policies following the war with Russia, we included a dummy variable labeled "Post-1767" (1 if year > 1767).

Another control variable is the number of records (probate inventories) that were used to calculate inequality measures each year. We have seen in Table 1 that the average number of records had a rising trend that was similar to the rise in wealth inequality. This raises the question of whether there might be some relationship between sample size and inequality measures. Although none of our measures are in principle sensitive to sample size, it is desirable to include the number of records in regression analysis to control for influences possibly arising from unobserved properties of the data source related to its size.

Finally, we included a time trend (in natural logs, taking 1713=1) to control for unobserved factors, such as variations in population or migration, that could be systematically growing over time. Including time trend in the analysis explicitly recognizes that wealth inequality could be growing over time for reasons unrelated to other explanatory variables and allows us to separate their individual effects.

***Table 4 should be about here***

Table 4 shows maximum likelihood estimates for a Tobit model of influences on wealth inequality. ${ }^{40}$ The results from Tables 1 and 4 suggest that the long-term rising trend in wealth

\footnotetext{
${ }^{40}$ The results are consistent with OLS model.
} 
inequality in Kastamonu in the eighteenth century was not caused by changes in the proportions of elites. The coefficients of the proportions of individuals with judicial/religious and military/administrative titles are both negative, indicating that the proportions of these groups would have had to fall over time for the total effect on inequality to be positive. Since these proportions did not fall during this period (Table 1), we conclude that changes in the proportions of elites fail to explain the rise in inequality.

In the same vein, rising inequality was not caused by other positional shifts in the population. Recall from Table 1 that the proportion of individuals with no titles rose significantly in the course of eighteenth century. ${ }^{41}$ Combined with the finding that this proportion had a negative effect on inequality, this result indicates that the total effect on inequality was negative. Although these results are certainly interesting for what they tell us about the relationship between honorary titles and inequality, they do not help us identify the causes of the rise in inequality.

Before proceeding to other results, we offer a brief discussion of how our results on honorary titles relates to one of the well-known developments in the economic history of the Ottoman Empire in the seventeenth and eighteenth centuries, namely the rising importance of tax-farming. ${ }^{42}$ Not only did tax-farming contracts become more numerous during this period, but their duration lengthened from three years or less to three to five years. The institution of lifeterm tax-farming (malikane) in 1695 further broadened opportunities for wealth accumulation. Although our records do not provide direct information on the identities of tax-farmers, we can

\footnotetext{
${ }^{41}$ We performed a t-test to confirm the statistical significance of the difference between the first and last periods.

${ }^{42}$ Darling, Revenue-Raising and Legitimacy; Pamuk, "The Evolution of Financial Institutions”; Salzmann, “An Ancien Régime Revisited"; and ibid. Tocqueville in the Ottoman Empire.
} 
use the information about elites as proxies for tax-farmers to comment on whether these developments contributed to rising inequality. ${ }^{43}$ As members of the provincial elite, elite titleholders possessed the influence and connections necessary to secure local tax-farming contracts and the means to make the required lump-sum payments, which is why they, more so than any other group, became involved in tax-farming arrangements in their own regions. ${ }^{44}$

Presuming individuals with elite titles to be more likely than others (in other words, nonelite title-holders and the title-less) to be tax-farmers, we can speculate from our results on the proportions of elites that the rising importance of tax-farming did not contribute to rising inequality. As noted, the proportions of judicial/religious and military/administrative elites remained fairly constant during our period (Table 2). Moreover, the coefficients of these proportions were generally negative (Table 4), suggesting that any rise in this segment of the population would have reduced inequality. In short, wealth inequality rose in Kastamonu during this period not because of changes in the extent of tax-farming or other positional shifts in population that reflected in honorary titles but despite these changes.

The effects of macroeconomic variables give mixed results when compared to other studies of inequality. Average wealth had a positive effect on wealth inequality, a result that has

\footnotetext{
${ }^{43}$ For arguments on how the spread of tax-farming contributed to inequality, see İnalc1k, "Military and Fiscal Transformation”; Özkaya, XVIII. Yüzyılda; McGowan, Economic Life; Genç, "Osmanlı Maliyesinde”; Çızakça, A Comparative Evolution, pp. 159-69.

${ }^{44}$ Ottomanists agree that the expanding tax-farming opportunities were generally seized by the local elite, who had strong connections with the provincial military/administrative and religious/judicial establishments. For details, see Pamuk, "The Evolution of Financial Institutions"; Marcus, Middle East, pp. 66-76; İnalc1k, “Centralization and Decentralization"; and Barkey, Empire of Difference, ch. 7. As supporting evidence for the high correlation between elites and tax-farmers, contemporary documents almost never refer to a tax-farmer without using an honorary title.
} 
been generally found in the literature for Europe during this period. The negative coefficient of price level, however, contradicts studies that have found a positive relationship between inflation and inequality in modern societies. ${ }^{45}$ Given that prices generally rose during the eighteenth century, our result indicates that inflation affected the values of assets owned by the rich and poor segments differently, in a way that reduced the gap between them.

Adverse shocks had interesting effects on wealth inequality. The immediate effect of warfare was consistently negative and mostly significant, indicating that consequences of Ottoman wars that were emphasized by Genç, Murphey, and others worked in such a way that the gap between the rich and the poor narrowed. The lagged effect of war on inequality was mostly positive but not very significant.

Extreme weather conditions did not have significant effects on inequality immediately, one exception being the case of the wealth of top 10 percent as the dependent variable. Whereas the lagged effect of wet conditions was negative but not always significant, that of dry conditions was generally positive and significant. As the most consistent weather-related result across different measures of inequality, the positive and significant coefficient of the lagged extreme dry conditions indicate that the wealthier members of the society were better able to deal with these conditions in the longer run than the poor who may have had to liquidate assets to survive.

Of the three factors included in the analysis to control for some of the other potential influences, the expectation that wealth inequality narrowed during the period after 1767 gets no support. Despite being significant only when the Gini coefficient is the dependent variable, the sign of "Post-1767" is generally positive, contrary to the expectation that the events and policies of this period reduced inequality. The positive and significant coefficient of time trend confirms

\footnotetext{
${ }^{45}$ Albanesi, "Inflation and Inequality."
} 
the expectation that wealth inequality grew over time for reasons unrelated to other explanatory variables. In particular, as noted, this happened despite the positional shifts among elites, individuals with non-elite titles, and others with no honorary titles.

\section{CONCLUSION}

Using information from the estate inventories of Kastamonu, this paper has contributed the first quantitative analysis of wealth inequality in the Ottoman Empire in the eighteenth-century. Our findings fill a significant gap in knowledge about the evolution and sources of inequality in this region before the modern period. Although economic historians of the Ottoman Empire have recently studied some of the significant economic, political, and institutional transformations of the eighteenth century, little was known about the way these transformations affected inequality. We expect our findings to stimulate further studies of inequality in other regions of the Empire and generate new perspectives on the patterns, sources, and consequences of wealth inequality.

Our results show that wealth inequality rose significantly in Kastamonu during the course of the eighteenth century, a pattern that was parallel to those observed in Europe prior to the industrial revolution. If future studies confirm this result in other regions of the Empire, they would indicate that it was not just the movement of prices that followed a parallel pattern between the region and Europe during this period but the evolution of inequalities and possibly other macroeconomic variables as well. They would force economic historians to question some of the widely held presumptions about the unique experience of the Ottoman Empire in economic development and to reexamine recent explanations for why the region fell behind. ${ }^{46}$

\footnotetext{
${ }^{46}$ As an example, the finding of rising inequality would cast doubt on the arguments of Kuran, The Long Divergence, and others that certain Islamic institutions caused economic underdevelopment by preventing the rise of
} 
Our analysis has also examined the sources of inequality. To determine the effect of changing social positions on the distribution of wealth, we employed information on honorary titles as recorded in court registers and used the proportions of judicial/religious and military/administrative elites as indicators of social positions. Using our results on honorary titles, we offer a speculation on the role of a significant transformation in Ottoman economy in the eighteenth century, namely the rise tax-farming, which has been viewed as widening inequality. Contrary to widely held presumptions, our results suggest that tax-farming did not contribute to the rise in inequality. We also examined the effects of macroeconomic variables (inflation and average wealth) and adverse shocks (wars and extreme weather conditions) on inequality and discussed how our findings confirm expectations raised by economic theory and recent literature on Ottoman Empire. 


\section{REFERENCES}

Albanesi, Stefania. "Inflation and Inequality." Journal of Monetary Economics 54, no. 4 (2007): 1088-1114.

Alesina, Alberto and Dani Rodrik. "Distributive Politics and Economic Growth." Quarterly Journal of Economics 109, no. 2 (1994): 465-490.

Akkemik, Ünal, Nesibe Dağdeviren, and Aliye Aras. “A Preliminary Reconstruction (A.D. 1635-2000) of Spring Precipitation Using Oak Tree Rings in the Western Black Sea Region of Turkey." International Journal of Biometeoroloji 49 (2005): 297-302.

Aksan, Virginia. Ottoman Wars, 1700-1800: An Empire Besieged. Harlow: Pearson, 2007.

Arrondel, Luc, and Cyril Grange. "Transmission and Inequality of Wealth: An Empirical Study of Wealth Mobility from 1800 to 1939 in France. Journal of Economic Inequality 4 (2006): 209-32.

Atkinson, A. B. and François Bourguignon. Handbook of Income Distribution. Vol. 16. New York: Elsevier, 2000.

Barkey, Karen. Empire of Difference: The Ottomans in Comparative Perspective. Cambridge: Cambridge University Press, 2008.

Cezar, Yavuz. Osmanlı Maliyesinde Bunalım ve Değişim Dönemi (XVIII. yy. dan Tanzimat'a Mali Tarih). Istanbul: Alan Yayınc1l1k, 1986.

Coşgel, Metin M. and Boğaç Ergene. "Intergenerational Wealth Accumulation and Dispersion in the Ottoman Empire: Observations from Eighteenth Century Kastamonu." European Review of Economic History 15 (2011): 255-76. 
Çizakça, Murat. A Comparative Evolution of Business Partnerships: The Islamic World and Europe. Leiden: Brill Publishers, 1996.

Darling, Linda. Revenue-Raising and Legitimacy; Tax Collection and Finance Administration in the Ottoman Empire, 1560-1660. Leiden: Brill Publishers, 1996.

Deininger, Klaus, and Lyn Squire. "New Ways of Looking at Old Issues: Inequality and Growth." Journal of Development Economics 57, no. 2 (1998): 259-287.

Ergene, Boğaç A. Local Court, Provincial Society and Justice in the Ottoman Empire: Legal Practice and Dispute Resolution in Çankırı and Kastamonu (1652-1744). Leiden: Brill Publishers, 2003. . "Costs of Court Usage in Seventeenth- and Eighteenth-century Ottoman Anatolia: Court Fees as Recorded in Estate Inventories." Journal of the Economic and Social History of the Orient 45 (2002): 20-39.

Ergene, Boğaç A., and Ali Berker. "Wealth and Inequality in 18th-Century Kastamonu: Estimations for the Muslim Majority.” International Journal of Middle East Studies 40 (2008): 23-40.

Eyüpgiller, Kemal K. Bir Kent Tarihi: Kastamonu. Istanbul: Eren Yayıncılık, 1999.

Faroqhi, Suraiya. Towns and Townsmen of Ottoman Anatolia; Trade, Crafts and Food Production in an Urban Setting, 1520 - 1650. Cambridge York: Cambridge University Press, 1984.

Faroqhi, Suraiya. "Declines and Revivals in Textile Production." The Cambridge History of Turkey, Vol. 1, edited by Suraiya Faroqhi, 356-375. Cambridge: Cambridge University Press, 2006. 
Genç, Mehmet. “A Study of the Feasibility of Using Eighteenth-Century Ottoman Financial Records as an Indicator of Economic Activity." In The Ottoman Empire and the World Economy, edited by Huri İslamoğlu-İnan, 345-373. Cambridge: Cambridge University Press, 1987.

Genç, Mehmet. "Osmanlı Ekonomisi ve Savaş." Yapıt 49 (1984): 52-61.

Genç, Mehmet. “Osmanlı maliyesinde Malikane Sistemi.” In Türkiye İktisat Tarihi Semineri: Metinler / Tartışmalar, edited by Osman Okyar, 231-91. Ankara: Hacettepe Üniversitesi Yayınlar1, 1973.

Heywood, Colin. "Kastamonu.” Encyclopedia of Islam. $2^{\text {nd }}$ ed. Leiden: E. J. Brill. 4 (1978): 738739.

Hoffman, Philip T., David Jacks, Patricia Levin, and Peter H. Lindert. "Real Inequality in Europe since 1500." Journal of Economic History 62, no. 2 (2002): 322-355.

Ibarraran, Maria E. and Matthias Ruth. "Climate Change and Natural Disasters: Economic and Distributional Impacts." In Distributional Impacts of Climate Change and Disasters: Concepts and Cases, edited by Maria E. Ibarraran, 46-66. Cheltenham, U.K. and Northampton, Mass.: Elgar, 2009.

İnalc1k, Halil. "Military and Fiscal Transformation in the Ottoman Empire, 1600-1700." Archivum Ottomanicum 6 (1980): 283-337.

İnalc1k Halil. "Centralization and Decentralization in Ottoman Administration.” In Studies in Eighteenth Century Islamic History, edited by Thomas Naff \& Roger Owen, 27-52. Carbondale, IL.: Southern Illinois University Press, 1977. 
Jones, Alice H. Wealth of a Nation to Be: The American Colonies on the Eve of the Revolution. New York: Columbia University Press, 1980.

İnalc1k, Halil and Donald Quataert. An Economic and Social History of the Ottoman Empire, 1300-1914. Cambridge: Cambridge University Press, 1994.

Karagöz, Mehmet. "XVII. ve XVIII. Asırlarda (1650-1750) Kayseri.” Firat University Journal of Social Science 19 (2009): 259-79.

Kasaba, Reşat. The Ottoman Empire and the World Economy: The Nineteenth Century. Albany: State University of New York, 1988.

Kinneir, John M. Journey through Asia Minor, Armenia, and Koordistan. London: John Murray, 1818.

Kuran, Timur. The Long Divergence: How Islamic Law Held Back the Middle East Princeton: Princeton University Press, 2010.

Kuznets, Simon. "Economic Growth and Income Inequality." American Economic Review 45 (1955): 1-28.

Main, Gloria L. "Probate Records as a Source for Early American History." William and Mary Quarterly 32 (1975): 89-99.

Marcus, Abraham. Middle East on the Eve of Modernity: Aleppo in the Eighteenth Century. New York: Columbia University Press, 1989.

McGowan, Bruce. Economic Life in the Ottoman Empire: Taxation, Trade and the Struggle for Land, 1600-1800. Cambridge: Cambridge University Press, 1981.

Murphey, Rhoads. Ottoman Warfare, 1500-1700. New Brunswick, N.J.: Rutgers University Press, 1998. 
Özkaya, Yücel. XVIII. Yüzyılda Osmanlı Kurumları ve Osmanlı Toplum Yaşantısı. Ankara: Kültür Bakanlığı Yayınları, 1985.

Özmucur, Süleyman and Şevket Pamuk. "Real Wages and the Standards of Living in the Ottoman Empire, 1469-1914.” Journal of Economic History 62 (2002): 293-321.

Pamuk, Şevket. "The Evolution of Financial Institutions in the Ottoman Empire, 1600-1914," Financial History Review 11 (2004): 7-32. . "Institutional Change and the Longevity of the Ottoman Empire, 1500-1800." Journal of Interdisciplinary History 35 (2004): 225-247.

Persson, Torsten and Guido Tabellini. "Is Inequality Harmful for Growth?" American Economic Review 84, no. 3 (1994): 600-621.

Piketty, Thomas, Gilles Postel-Vinay, and Jean-Laurent Rosenthal. "Wealth Concentration in a Developing Economy: Paris and France, 1807-1994." American Economic Review 96, no. 1 (2006): 236-256.

Salzmann, Ariel. "An Ancien Régime Revisited: "Privatization" and Political Economy in the Eighteenth-Century Ottoman Empire," Politics \& Society 21 (1993): 393-423. . "Measures of Empire: Tax Farmers and the Ottoman Ancien Régime, 16951807,” Ph.D. Dissertation, Columbia University, 1995. . Tocqueville in the Ottoman Empire: Rival Paths to the Modern State. Leiden: Brill Publishers, 2004. 
Silberling, Norman J. The Dynamics of Business; an Analysis of Trends, Cycles, and Time Relationships in American Economic Activity since 1700 and their Bearing upon Governmental and Business Policy. New York: McGraw-Hill Book Company, 1943.

Soltow, Lee and J. L. van Zanden. Income and Wealth Inequality in the Netherlands, 16th-20th Century. Amsterdam: Het Spinhuis, 1998.

Tabakoğlu, Ahmet. Gerileme Dönemine Girerken Osmanlı Maliyesi. Istanbul: Dergah Yayınları, 1985.

Yaman, Talat. "Küre Bakır Madenine Dair Vesikalar.” Tarih Vesikaları 1 (1941): 266-82.

van Zanden, Jan Luiten. "Inequality of Wealth of Income Distribution.” In Oxford Encyclopedia of Economic History, edited by Joel Mokyr, vol. 3, 56-59. Oxford: Oxford University Press, 2003.

Wrigley, E.A., and R.S. Schofield. The Population History of England, 1541-1871: A Reconstruction. Cambridge: Cambridge University Press, 2002.

White, Sam. "Ecology, Climate, and Crisis in the Ottoman Near East.” Ph.D. Dissertation, Columbia University, 2008. 
Table 1

Wealth Inequality over Time

(Annual Averages)

\begin{tabular}{|l|r|r|r|r|r|r|}
\hline & \multicolumn{7}{|c|}{ PERIOD } \\
\hline & & & & & $1790-$ & ALL \\
VARIABLE & $1713-29$ & $1730-49$ & $1750-69$ & $1770-89$ & 1802 & YEARS \\
\hline & 1.14 & 1.47 & 1.81 & 1.86 & 1.66 & 1.62 \\
Coefficient of variation & $(0.31)$ & $(0.59)$ & $(0.60)$ & $(0.67)$ & $(0.47)$ & $(0.59)$ \\
\hline & 0.52 & 0.58 & 0.64 & 0.65 & 0.61 & 0.60 \\
Gini coefficient & $(0.09)$ & $(0.11)$ & $(0.08)$ & $(0.12)$ & $(0.06)$ & $(0.10)$ \\
\hline & 0.36 & 0.44 & 0.49 & 0.52 & 0.47 & 0.46 \\
Share of wealthiest 10\% & $(0.09)$ & $(0.21)$ & $(0.11)$ & $(0.15)$ & $(0.07)$ & $(0.14)$ \\
\hline & 0.62 & 0.67 & 0.74 & 0.74 & 0.69 & 0.70 \\
Share of wealthiest 25\% & $(0.11)$ & $(0.12)$ & $(0.08)$ & $(0.11)$ & $(0.06)$ & $(0.10)$ \\
\hline & 748.70 & 1159.89 & 1135.07 & 1308.98 & 1861.64 & 1246.36 \\
Average wealth (guruş) & $(268.02)$ & $(750.50)$ & $(515.00)$ & $(613.92)$ & $(777.21)$ & $(679.16)$ \\
\hline Consumer price index & 6.76 & 8.55 & 10.37 & 16.72 & 24.80 & 13.35 \\
(Akçe) & $(0.38)$ & $(1.89)$ & $(1.62)$ & $(1.62)$ & $(2.06)$ & $(6.59)$ \\
\hline Number of records & 17.57 & 17.00 & 48.09 & 50.67 & 41.38 & 36.18 \\
(Probate inventories) & $(6.75)$ & $(7.33)$ & $(11.38)$ & $(21.83)$ & $(11.29)$ & $(11.29)$ \\
\hline
\end{tabular}

Note: Figures in parentheses are the standard errors.

Sources: Probate estate inventories (terekes) as found in the court records (sicils) of Kastamonu.

See the text for calculation of net wealth. Consumer price index is from Özmucur and Pamuk,

"Real Wages". 
Table 2

\section{Positional Shifts and Inequality}

\section{(Annual Averages)}

\begin{tabular}{|c|c|c|c|c|c|c|c|}
\hline & \multicolumn{6}{|c|}{ PERIOD } & AVERAGE \\
\hline VARIABLE & $1713-29$ & $1730-49$ & $1750-69$ & $1770-89$ & $\begin{array}{r}1790- \\
1802 \\
\end{array}$ & $\begin{array}{r}\text { ALL } \\
\text { YEARS }\end{array}$ & $\begin{array}{r}\text { REAL } \\
\text { WEALTH } \\
\text { BY } \\
\text { GROUP }\end{array}$ \\
\hline $\begin{array}{l}\text { Proportion of } \\
\text { judicial/religious elites }\end{array}$ & $\begin{array}{r}0.06 \\
(0.07) \\
\end{array}$ & $\begin{array}{r}0.11 \\
(0.09) \\
\end{array}$ & $\begin{array}{r}0.08 \\
(0.03) \\
\end{array}$ & $\begin{array}{r}0.07 \\
(0.02) \\
\end{array}$ & $\begin{array}{r}0.08 \\
(0.03) \\
\end{array}$ & $\begin{array}{r}0.08 \\
(0.05) \\
\end{array}$ & $\begin{array}{r}188.8 \\
(374.6)\end{array}$ \\
\hline $\begin{array}{l}\text { Proportion of } \\
\text { military/administrative } \\
\text { elites }\end{array}$ & $\begin{array}{r}0.06 \\
(0.08)\end{array}$ & $\begin{array}{r}0.11 \\
(0.07)\end{array}$ & $\begin{array}{r}0.09 \\
(0.06)\end{array}$ & $\begin{array}{r}0.10 \\
(0.05)\end{array}$ & $\begin{array}{r}0.10 \\
(0.04)\end{array}$ & $\begin{array}{r}0.09 \\
(0.06)\end{array}$ & $\begin{array}{r}261.7 \\
(509.8)\end{array}$ \\
\hline $\begin{array}{l}\text { Proportion of } \\
\text { individuals with non- } \\
\text { elite titles }\end{array}$ & $\begin{array}{r}0.45 \\
(0.12) \\
\end{array}$ & $\begin{array}{r}0.31 \\
(0.15) \\
\end{array}$ & $\begin{array}{r}0.31 \\
(0.08) \\
\end{array}$ & $\begin{array}{r}0.29 \\
(0.15) \\
\end{array}$ & $\begin{array}{r}0.26 \\
(0.08) \\
\end{array}$ & $\begin{array}{r}0.32 \\
(0.13) \\
\end{array}$ & $\begin{array}{r}62.5 \\
(122.0) \\
\end{array}$ \\
\hline $\begin{array}{l}\text { Proportion of } \\
\text { individuals with no } \\
\text { titles }\end{array}$ & $\begin{array}{r}0.43 \\
(0.11)\end{array}$ & $\begin{array}{r}0.47 \\
(0.09)\end{array}$ & $\begin{array}{r}0.53 \\
(0.07) \\
\end{array}$ & $\begin{array}{r}0.54 \\
(0.13) \\
\end{array}$ & $\begin{array}{r}0.57 \\
(0.09) \\
\end{array}$ & $\begin{array}{r}0.51 \\
(0.10) \\
\end{array}$ & $\begin{array}{r}88.2 \\
(242.6) \\
\end{array}$ \\
\hline
\end{tabular}

Note: Figures in parentheses are the standard errors.

Source: Probate estate inventories (terekes) as found in the court records (sicils) of Kastamonu.

See the text for the classification of elites from honorary titles and the calculation of net wealth. 
Table 3

War, Weather, and Wealth Inequality

\begin{tabular}{|l|c|c|c|c|}
\hline & $\begin{array}{l}\text { Coefficient of } \\
\text { Variation }\end{array}$ & Gini Coefficient & $\begin{array}{l}\text { Share of } \\
\text { Wealthiest 10\% }\end{array}$ & $\begin{array}{l}\text { Share of } \\
\text { Wealthiest 25\% }\end{array}$ \\
\hline Peace & 1.69 & 0.62 & 0.49 & 0.71 \\
& $(0.60)$ & $(0.09)$ & $(0.11)$ & $(0.09)$ \\
\hline War & 1.54 & 0.59 & 0.43 & 0.68 \\
& $(0.58)$ & $(0.11)$ & $(0.16)$ & $(0.11)$ \\
\hline Dry & 1.90 & 0.65 & 0.50 & 0.75 \\
& $(0.67)$ & $(0.08)$ & $(0.16)$ & $(0.07)$ \\
\hline Normal & 1.55 & 0.59 & 0.47 & 0.68 \\
& $(0.55)$ & $(0.10)$ & $(0.12)$ & $(0.11)$ \\
\hline Wet & 1.63 & 0.60 & 0.33 & 0.71 \\
& $(0.69)$ & $(0.11)$ & $(0.23)$ & $(0.12)$ \\
\hline \multirow{3}{*}{ All years } & 1.62 & 0.60 & 0.46 & 0.70 \\
& $(0.59)$ & $(0.10)$ & $(0.14)$ & $(0.10)$ \\
\hline
\end{tabular}

Note: Figures in parentheses are the standard errors.

Sources: Wealth data is from probate estate inventories (terekes) as found in the court records (sicils) of Kastamonu. For the calculation of net wealth, see the text; for war/peace years, see note \#45; for precipitation data, see Akkemik, Dağdeviren, and Aras, “A Preliminary Reconstruction.” 
Table 4

Sources of Wealth Inequality

\begin{tabular}{|c|c|c|c|c|}
\hline & \multicolumn{4}{|c|}{ DEPENDENT VARIABLE } \\
\hline EXPLANATORY VARIABLES & $\begin{array}{l}\text { Coefficient } \\
\text { of Variation }\end{array}$ & $\begin{array}{l}\text { Gini } \\
\text { Coefficient }\end{array}$ & $\begin{array}{l}\text { Share of } \\
\text { Wealthiest } 10 \\
\%\end{array}$ & \begin{tabular}{|l|} 
Share of \\
Wealthiest \\
$25 \%$ \\
\end{tabular} \\
\hline $\begin{array}{l}\text { Proportion of judicial/religious } \\
\text { elites }\end{array}$ & $\begin{array}{r}-0.74 \\
(0.85) \\
\end{array}$ & $\begin{array}{r}-0.27 * * \\
(0.16) \\
\end{array}$ & $\begin{array}{r}-0.52 * * \\
(0.26) \\
\end{array}$ & $\begin{array}{r}-0.35 * * \\
(0.18) \\
\end{array}$ \\
\hline $\begin{array}{l}\text { Proportion of } \\
\text { military/administrative elites }\end{array}$ & $\begin{array}{r}-1.25^{*} \\
(0.76)\end{array}$ & $\begin{array}{r}-0.10 \\
(0.14)\end{array}$ & $\begin{array}{r}-0.45^{* *} \\
(0.23)\end{array}$ & $\begin{array}{r}-0.12 \\
(0.16)\end{array}$ \\
\hline $\begin{array}{l}\text { Proportion of individuals with no } \\
\text { titles }\end{array}$ & $\begin{array}{r}-1.97 * * * \\
(0.50) \\
\end{array}$ & $\begin{array}{r}-0.28 * * * \\
(0.09) \\
\end{array}$ & $\begin{array}{r}-0.44 * * * \\
(0.15) \\
\end{array}$ & $\begin{array}{r}-0.25 * * \\
(0.11) \\
\end{array}$ \\
\hline $\begin{array}{l}\text { Average wealth } \\
\text { (guruş, natural } \log )\end{array}$ & $\begin{array}{r}0.85^{* * * *} \\
(0.11) \\
\end{array}$ & $\begin{array}{r}0.16^{* * * *} \\
(0.02) \\
\end{array}$ & $\begin{array}{r}0.19 * * * \\
(0.03) \\
\end{array}$ & $\begin{array}{r}0.16^{* * *} \\
(0.02) \\
\end{array}$ \\
\hline $\begin{array}{l}\text { Consumer price index } \\
\text { (Akçe, natural log) }\end{array}$ & $\begin{array}{r}-0.65^{* *} \\
(0.27)\end{array}$ & $\begin{array}{r}-0.12 * * * \\
(0.05)\end{array}$ & $\begin{array}{c}-0.11^{*} \\
(0.08)\end{array}$ & $\begin{array}{r}-0.13^{* *} \\
(0.06)\end{array}$ \\
\hline War & $\begin{array}{r}-0.25 * * \\
(0.14) \\
\end{array}$ & $\begin{array}{r}-0.06^{* *} \\
(0.03) \\
\end{array}$ & $\begin{array}{l}-0.06^{*} \\
(0.04) \\
\end{array}$ & $\begin{array}{l}-0.03 \\
(0.03) \\
\end{array}$ \\
\hline Lag War $\left(\mathrm{War}_{\mathrm{t}-1}\right)$ & $\begin{array}{r}0.22 * \\
(0.15) \\
\end{array}$ & $\begin{array}{r}0.03 \\
(0.03) \\
\end{array}$ & $\begin{array}{r}-0.002 \\
(0.04) \\
\end{array}$ & $\begin{array}{r}0.02 \\
(0.03) \\
\end{array}$ \\
\hline Dry & $\begin{array}{r}0.01 \\
(0.12) \\
\end{array}$ & $\begin{array}{r}-0.004 \\
(0.02) \\
\end{array}$ & $\begin{array}{l}-0.05^{*} \\
(0.03) \\
\end{array}$ & $\begin{array}{r}0.02 \\
(0.02) \\
\end{array}$ \\
\hline Lag Dry $\left(\right.$ Dryt $\left._{\mathrm{t}-1}\right)$ & $\begin{array}{r}0.46 * * \\
(0.23) \\
\end{array}$ & $\begin{array}{r}0.12 * * * * \\
(0.04) \\
\end{array}$ & $\begin{array}{r}0.15^{* *} \\
(0.07) \\
\end{array}$ & $\begin{array}{r}0.02 \\
(0.05) \\
\end{array}$ \\
\hline Wet & $\begin{array}{r}-0.01 \\
(0.17)\end{array}$ & $\begin{array}{r}0.01 \\
(0.03)\end{array}$ & $\begin{array}{r}-0.12 * * \\
(0.05)\end{array}$ & $\begin{array}{r}0.03 \\
(0.04)\end{array}$ \\
\hline Lag Wet $\left(\right.$ Wet $\left._{t-1}\right)$ & $\begin{array}{r}-0.03 \\
(0.12) \\
\end{array}$ & $\begin{array}{r}-0.02 \\
(0.02) \\
\end{array}$ & $\begin{array}{l}-0.06^{*} \\
(0.04) \\
\end{array}$ & $\begin{array}{r}-0.01 \\
(0.03) \\
\end{array}$ \\
\hline Post-1767 & $\begin{array}{r}0.16 \\
(0.20) \\
\end{array}$ & $\begin{array}{l}0.06^{*} \\
(0.04) \\
\end{array}$ & $\begin{array}{r}0.01 \\
(0.06) \\
\end{array}$ & $\begin{array}{r}0.05 \\
(0.04) \\
\end{array}$ \\
\hline $\begin{array}{l}\text { Number of records } \\
\text { (Probate Inventories) }\end{array}$ & $\begin{array}{r}0.018 * * * \\
(0.003) \\
\end{array}$ & $\begin{array}{r}0.002 * * * \\
(0.001) \\
\end{array}$ & $\begin{array}{r}0.003 * * * \\
(0.001) \\
\end{array}$ & $\begin{array}{r}0.002 * * * * \\
(0.001) \\
\end{array}$ \\
\hline $\begin{array}{l}\text { Time } \\
(1713=1, \text { natural } \log )\end{array}$ & $\begin{array}{r}0.16^{* *} \\
(0.08) \\
\end{array}$ & $\begin{array}{r}0.03 * * \\
(0.02) \\
\end{array}$ & $\begin{array}{r}0.04 * \\
(0.03) \\
\end{array}$ & $\begin{array}{r}0.03^{*} \\
(0.02) \\
\end{array}$ \\
\hline Constant & $\begin{array}{r}-2.75^{* * *} \\
(0.66) \\
\end{array}$ & $\begin{array}{r}-0.23^{* *} \\
(0.12)\end{array}$ & $\begin{array}{r}-0.49 * * * \\
(0.20)\end{array}$ & $\begin{array}{r}-0.11 \\
(0.14)\end{array}$ \\
\hline$N$ & 44 & 44 & 44 & 44 \\
\hline Likelihood Ratio (Chi-squared) & $72.8 * * *$ & $66.6^{* * * *}$ & $54.7 * * *$ & $56.5 * * *$ \\
\hline
\end{tabular}

Notes:

a. Figures in parentheses are standard errors.

b. $* * *$ indicates significance at $1 \%, * *$ at $5 \%$, and $*$ at $10 \%$ for a one-tailed test.

c. Omitted variable is "Proportion of individuals with non-elite titles". 
Sources: Wealth data from probate estate inventories (terekes) as found in the court records (sicils) of Kastamonu. For the calculation of net wealth and the classification of elites from honorary titles, see the text; for war/peace years, see note \#45; for precipitation data, see Akkemik, Dağdeviren, and Aras, "A Preliminary Reconstruction”; for consumer price index, see Özmucur and Pamuk, "Real Wages”. 
Figure 1

\section{Rising Inequality in Kastamonu}

\section{(10 year moving averages)}
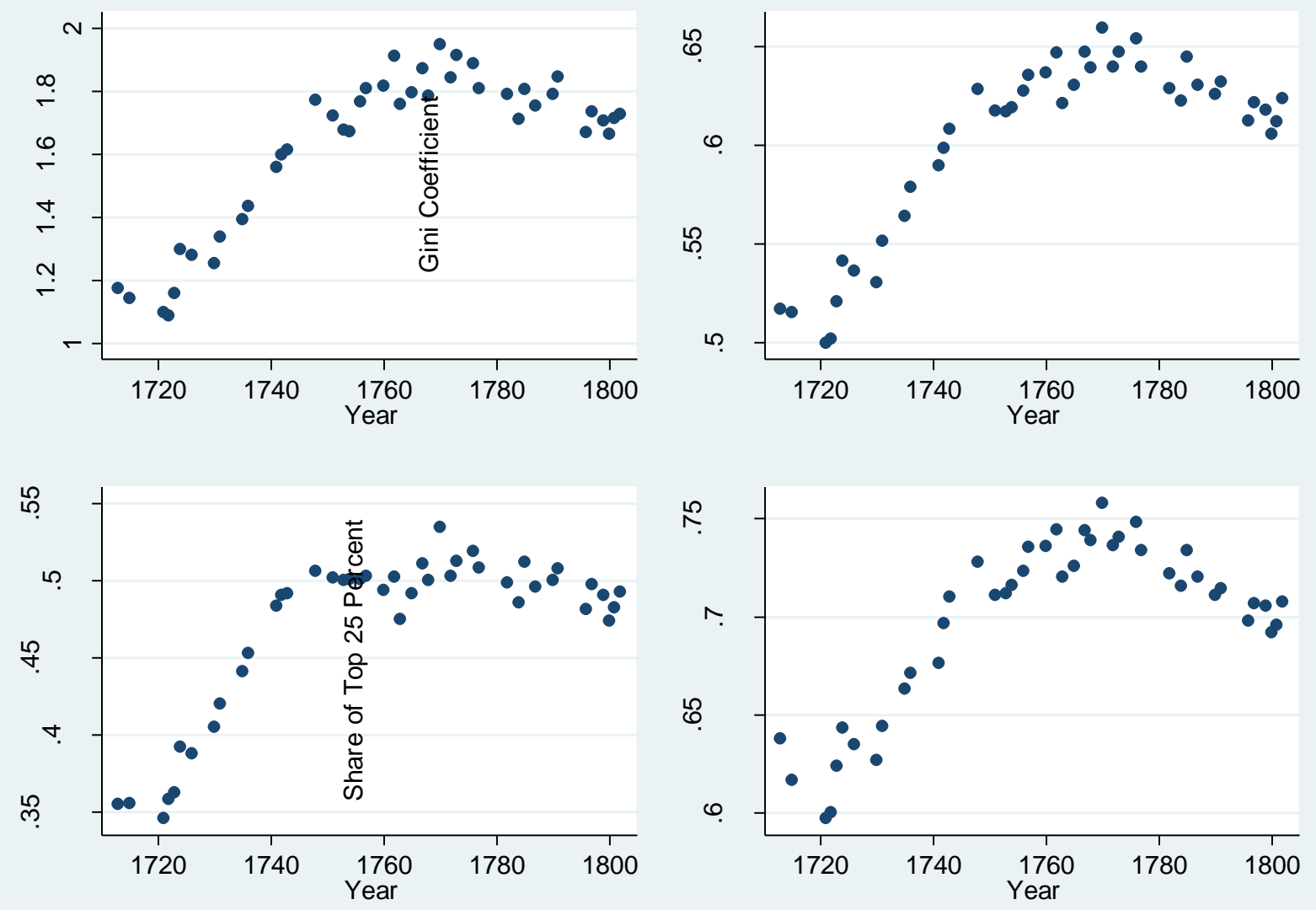